\title{
A Leaf Inoculation Method for Detection of Xanthomonas oryzae pv. oryzicola from Rice Seed
}

G. L. Xie, Plant Protection Department, Zhejiang Agricultural University, 310029 Hangzhou, People's Republic of. China; and T. W. Mew, Entomology and Plant Pathology Division, International Rice Research Institute, P.O. Box 933, Manila 1099, Philippines

\begin{abstract}
Xie, G. L., and Mew, T. W. 1998. A leaf inoculation method for detection of Xanthomonas oryzae pv. oryzicola from rice seed. Plant Dis. 82:1007-1011.

A leaf-inoculation method for detecting Xanthomonas oryzae pv. oryzicola in rice seed was developed and tested. The method is based on inoculating leaf segments on agar with seed washings in a moist chamber. Freshness of inoculated leaf segments is maintained by addition of 75 to $100 \mathrm{ppm}$ benzimidazole to the $1 \%$ water agar after sterilization. Using cells from pure cultures, the minimum inoculum concentration to initiate leaf streak lesions on the segments was found to be $10^{3} \mathrm{CFU} / \mathrm{ml}$. Inoculum prepared from seeds harvested from severely infected mother plants induced lesions typical of leaf streak, followed by bacterial ooze. With $4 \mathrm{~g}$ of seed, the incubation period was 3.5 days and bacterial ooze appeared within 5 days. The minimum amount of seed needed to detect the bacterium based on seed washings varied according to disease severity of the mother plants. The bacteria isolated from lesions on the leaf segments were confirmed as $X$. oryzae pv. oryzicola after bacteriological, serological, and Biolog tests were conducted. The results confirm that the detached-leaf method is as simple and reliable as the immuno-radiometric assay and inoculation on intact pot-grown rice plants in the greenhouse.
\end{abstract}

Additional keywords: bacterial leaf streak, disease diagnosis, quarantine

Bacterial leaf streak (BLS) of rice, caused by Xanthomonas oryzae pv. oryzicola $(3,4,15)$, has been considered a quarantine disease in China since the 1960s and has gained greater importance in many Asian countries. The bacterial pathogen is both seedborne and seed-transmitted $(4,5,9,13)$. The risk of BLS spread has increased with the movement of rice germ plasm in rice improvement activities at the international and national levels. In the late 1950 s, the disease was reported in only two provinces of south China $(4,7,17)$. The disease has since spread from the southern to the western, eastern, and central parts of the country, covering more than 10 provinces $(7,12,17)$. Recently, it has become one of the four major diseases of rice in China (the other three being blast, sheath blight, and bacterial blight); the damage caused by the disease is, in many instances, as severe as that caused by bacterial blight $(7,12,13,17)$.

Seed movement must be regulated on the basis of sound biology, and seed detection methods must be well established to

Corresponding author: T. W. Mew

E-mail: T.Mew@cgnet.com

Accepted for publication 29 May 1998.

Publication no. D-1998-0710-01R

(C) 1998 The American Phytopathological Society effectively restrict dissemination of most pathogens $(5,8,17)$. Methods for detection of seedborne bacteria, such as the growingon and plant injection or inoculation tests

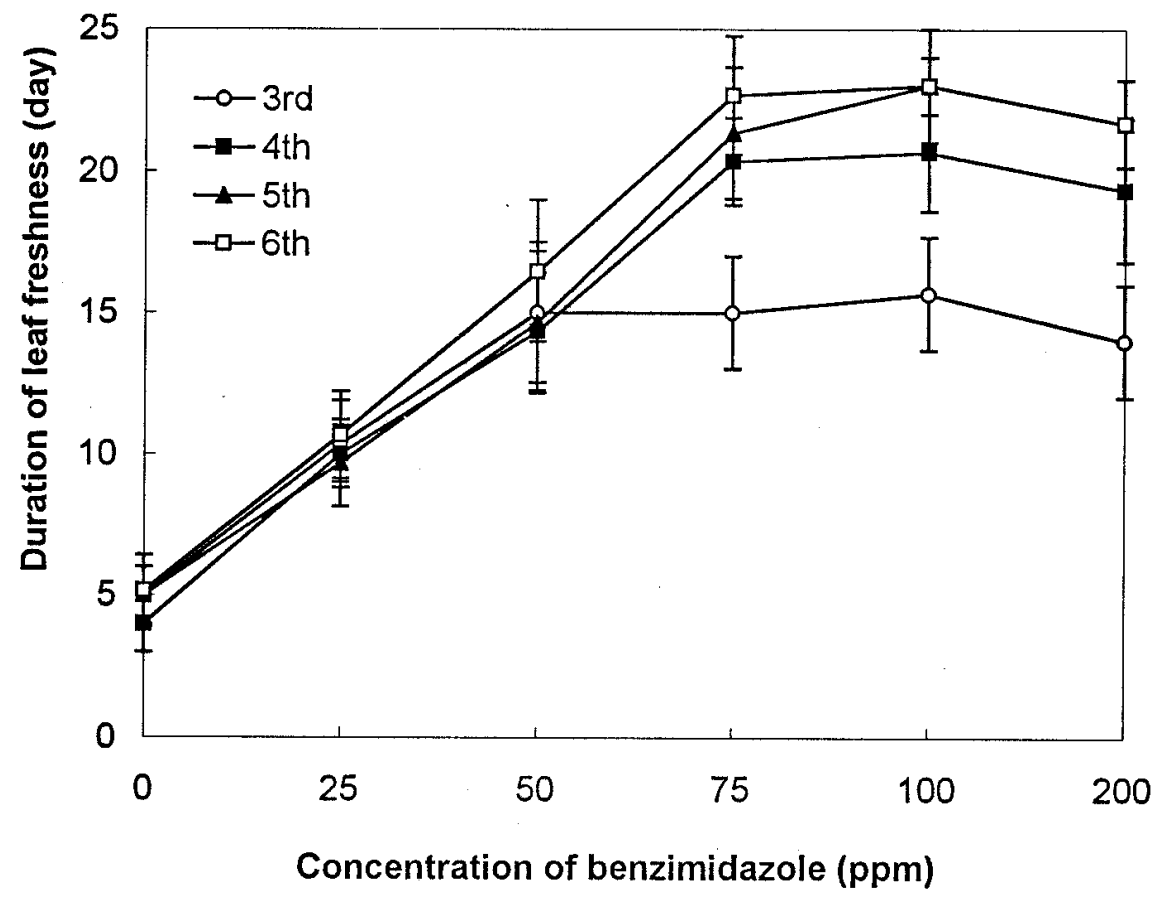

Fig. 1. Effect of benzimidazole incorporated in $1 \%$ water agar on the duration of freshness (greenness) of rice leaf segments incubated in petri dishes. Bars are standard deviations of three replications. (The figures of third, fourth, fifth, and sixth denoted the leaf position of the rice plant where leaf segments were taken in the experiments.)
$(5,14,17,18)$, produce variable results. An immuno-radiometric assay (IRMA; 19), enzyme-linked immunosorbent assay (ELISA), and monoclonal antibodies $(1,17,19)$ have been developed to detect $X$. oryzae pv. oryzicola. However, there are limitations to the use of these methods in routine seed-health testing of a large volume of seed samples. More importantly, these methods do not differentiate living from dead cells. Cross-reactions with $X$. oryzae pv. oryzae and other bacteria are observed in some cases (17-19). These techniques also require specific laboratory equipment and processing cost is high. Therefore, none of these methods is regularly used in routine rice seed health testing $(5,10,11)$.

This paper describes a rice leaf-inoculation method for detecting $X$. oryzae pv. oryzicola in rice seed. This method is practical and useful for the detection of bacteria and is used routinely in some plant quarantine stations in China.

\section{MATERIALS AND METHODS}

Samples for assay. Rice seed samples were collected from farmer's fields with 
slight (1 to $10 \%$ of leaf area), intermediate (20 to $30 \%$ ), and severe (more than $40 \%$ ) BLS severity. To ensure efficiency, individual rice panicles with flag leaves displaying various degrees of disease symptoms of bacterial blight (BB) and BLS were collected from fields at crop maturity. Two sets of experiments were conducted in China and one was done independently at the International Rice Research Institute (IRRI; Los Banos, Philippines). Seed was collected from China (64 samples) and from the Philippines (52 samples), at 200 to $400 \mathrm{~g}$ per sample.

Rice leaves with BLS and BB lesions and pure cultures of $X$. oryzae pv. oryzicola strain BLS335 from the Philippines and S872 from China were used for checks or antigen. Strain PXO 61, race 1 of $X$. oryzae pv. oryzae, and a strain of Acidovorax avenae subsp. avenae (Pseudomonas avenae) collected from IRRI, also served as checks.

Healthy seed of variety TN1 (Philippines) and Guang Ru-ai 4 (China) was grown in pots containing steamed soil and maintained in the greenhouse. Excessive $\mathrm{N}$ fertilizer was applied. Leaves from rice plants at the 3- to 6-leaf stage were used for the assay.

Leaf inoculation. To prepare the inoculum, 1 to $20 \mathrm{~g}$ of seed was used. Seeds were washed by shaking them for $2 \mathrm{~h}$ in sterile $1 \%$ peptone at a ratio of $1: 5$ (wt/vol). The suspension was filtered through filter paper (Whatman \# 1) to remove the seeds. The suspension was centrifuged at 13,000 rpm for $5 \mathrm{~min}$. The resuspended sediments were used as inoculum for the detection of bacteria. In a similar manner, inoculum was prepared from diseased leaves. Diseased leaves (2 to $4 \mathrm{~g}$ ) from each sample were cut into small pieces and washed in $1 \%$ peptone at a ratio of 1:5 (wt/vol). The leaf pieces also were soaked in peptone water for $2 \mathrm{~h}$, then removed by filtration. The suspension was centrifuged and the resuspended sediments were used for bacterial detection.

Rice leaves from the greenhouse-grown TN1 (in the Philippines) or Guang Ru-ai 4 (in China) were sampled at different growth stages from the third to the sixth leaf position and cut into 5- to $6-\mathrm{cm}$ segments. The segments were washed twice with sterile distilled water, then placed adaxial-side-up on the surface of water agar plates. The water agar $(1 \%, \mathrm{wt} / \mathrm{vol})$ was prepared by adding, after sterilization, a suspension of benzimidazole to obtain concentrations of $25,50,75,100$, and 200 ppm in $25 \mathrm{ml}$ medium per plate.

The leaf segments were inoculated by pricking them with small needles dipped into the leaf or seed wash suspensions. Some leaf segments were inoculated with pure cultures of $X$. oryzae pv. oryzicola or the other bacteria at $10^{8} \mathrm{CFU} / \mathrm{ml}$ as controls.

Incubation and observation. The agar plates with inoculated leaf segments were

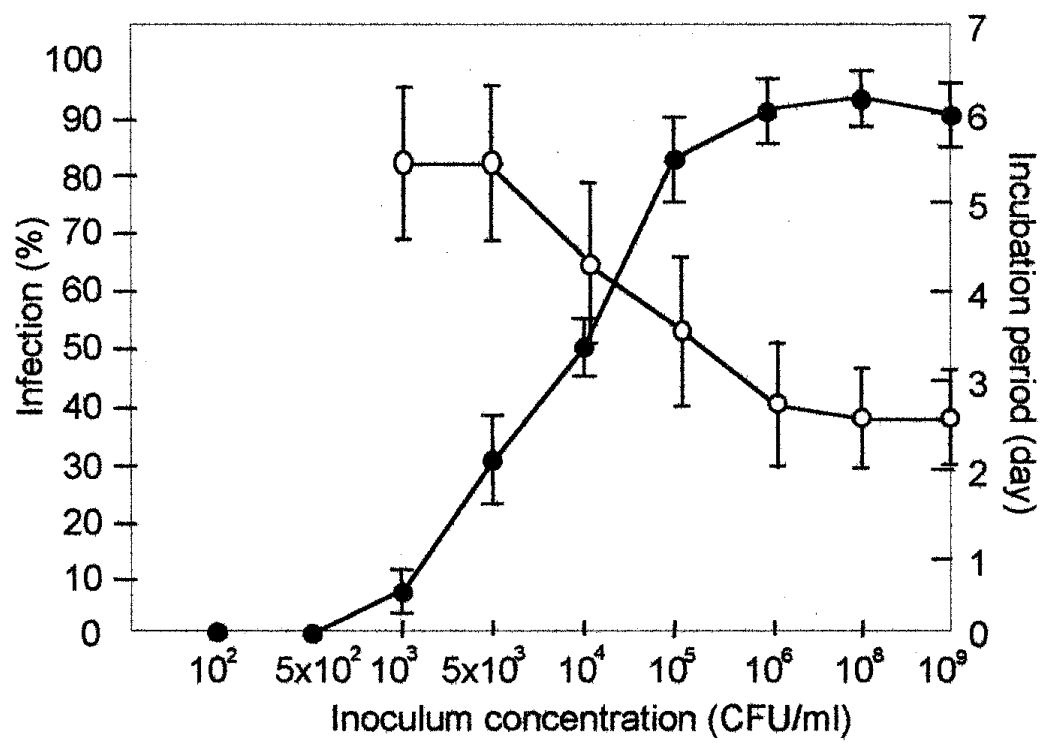

Fig. 2. Relationship of Xanthomonas oryzae pv. oryzicola inoculum concentration with $\boldsymbol{\bullet}$ = bacterial leaf streak severity and $\bigcirc=$ length of incubation period (time required for visible lesions to appear) of bacterial leaf streak on rice leaf segments in the leaf inoculation. Bars are standard deviations of three replications.
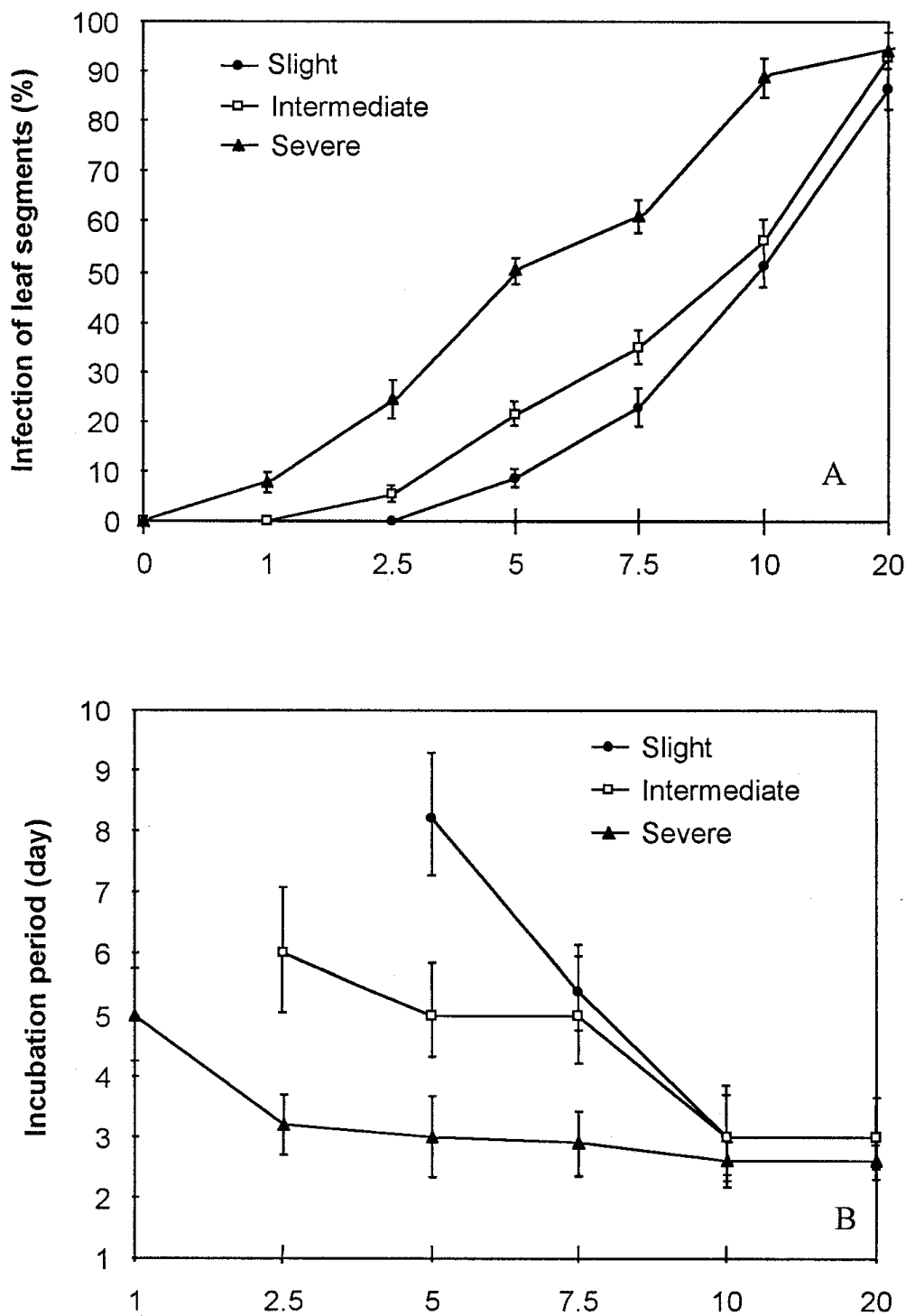

Fig. 3. Relationship of seed sample sizes (g) from mother plants with slight, intermediate, and severe bacterial leaf streak on (A) disease severity and (B) length of incubation period (time required for visible lesions to appear) in the rice leaf inoculation. Bars are standard deviations of three replications. 
incubated in a growth chamber (Percival, Boone, Iowa) at $32 / 25^{\circ} \mathrm{C}$ (day/night) with $12 \mathrm{~h} /$ day of fluorescent light (GE Fluorescent Lamp, General Electric, Manila, Philippines). Moisture was maintained by gently spraying a fine mist of sterile distilled water on the segments each day. Symptom development, as well as the appearance of ooze, was monitored for 4 weeks after inoculation.

Confirmation tests. To confirm the reliability of the leaf assay method, bacteria were re-isolated from the leaf segments 2 to 3 days after inoculation. Bacteriological tests using the methods of Vera Cruz et al. (16) were followed.

The Biolog system (Microlog 1 Release 3.50, Biolog Inc., Hayward, CA), based on patterns of carbon source utilization, also was used to confirm identity of the bacteria. The modified procedures of Xie were followed (18).

The bacteria re-isolated from the lesions on the leaf segments also were confirmed by the tube precipitin test (micro-agglutination) following the procedures of Ball (2). A twofold serial dilution series (1:2 to 1:512) of antiserum against $X$. oryzae pv. oryzicola was produced and used for confirmation. Another serological methodIRMA (19)—was used to compare results obtained from the leaf inoculation method. The IRMA combined the antibody in the antiserum with the protein A labeled with radioactive $\mathrm{I}^{125}$. When this radioactive $\mathrm{I}^{125}$-labeled antiserum was used in the test, the higher the inoculum concentration of $X$. oryzae pv. oryzicola, the higher the radioactive reading that was registered.

\section{RESULTS}

The duration of the green appearance of the leaf segments on water agar with benzimidazole added was prolonged when compared with the check. Duration of the green appearance was increased as concentration of benzimidazole increased, up to 75 ppm (Fig. 1). However, at a concentration higher than $75 \mathrm{ppm}$, duration was not increased for leaves taken from any position.

Inoculum concentration for inducing lesions. To determine the minimum amount of $X$. oryzae pv. oryzicola required to initiate BLS lesions on the leaf segments, bacteria were re-isolated from the diseased leaf segments and re-inoculated at different concentrations to the leaf segments placed on water agar amended with 75 ppm benzimidazole. With an increase in inoculum density, the number of BLS lesions also increased (Fig. 2). At inoculum concentrations lower than $10^{3} \mathrm{CFU} / \mathrm{ml}$, no visible lesions were observed on the leaf segments at the end of the experiments, 10 days after inoculation. An inoculum concentration of $10^{3} \mathrm{CFU} / \mathrm{ml}$ with an incubation period (the time required for visible lesions to appear from inoculation) of 6

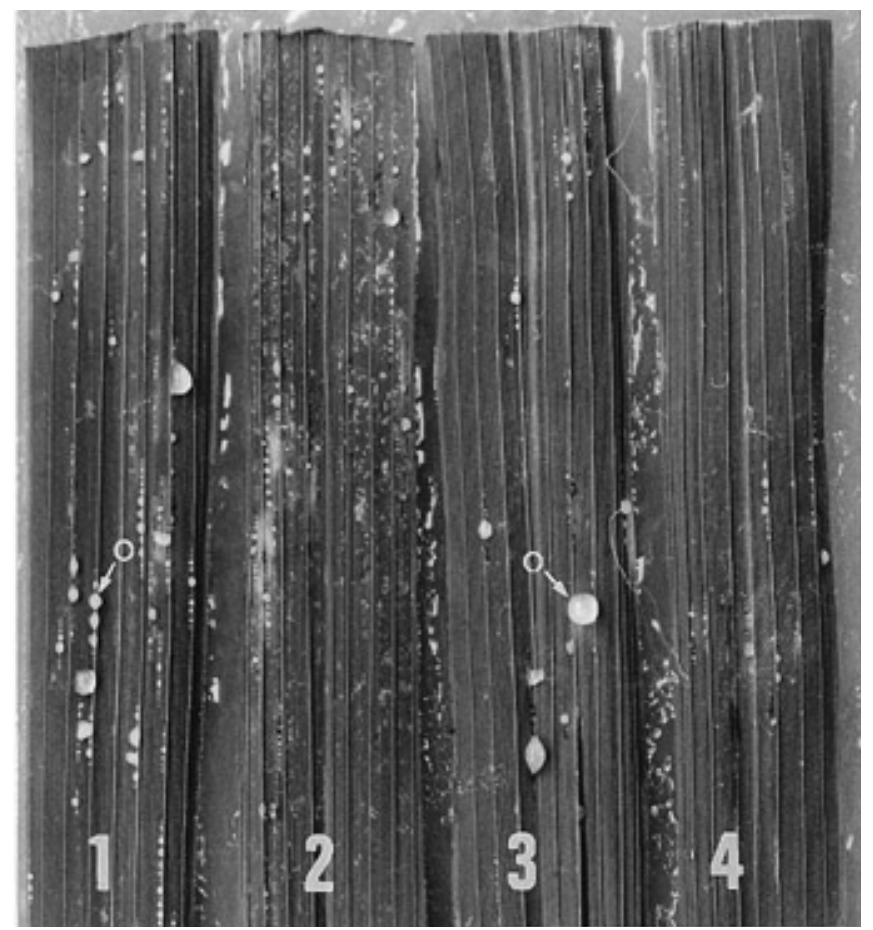

Fig. 4. Bacterial ooze (O) on streak lesions of leaf segments 14 days after inoculation with pure culture of Xanthomonas oryzae pv. oryzicola isolated from seed wash of rice seeds estimated with $10^{6} \mathrm{CFU} / \mathrm{ml}$ (leaf segments 1 and 2) and $10^{3} \mathrm{CFU} / \mathrm{ml}$ (leaf segments 3 and 4).

Table 1. Bacteriological tests of Xanthomonas oryzae pv. oryzicola (Xoc), X. oryzae pv. oryzae (Xoo), and Acidovorax avenae subsp. avenae (Aaa) re-isolated from lesions of leaf segments

\begin{tabular}{lccccc}
\hline Tests & Xoc $^{\mathbf{u}}$ & $\mathbf{X o c}^{\mathbf{v}}$ & $\mathbf{X o o}^{\mathbf{w}}$ & $\mathbf{X o o}^{\mathbf{x}}$ & Aaa $^{\mathbf{y}}$ \\
\hline Gram staining & $-\mathrm{z}$ & - & - & - & - \\
Fluorescence & - & - & - & - & - \\
Nitrate reduction & - & - & - & - & + \\
Oxidation-fermentation & $\mathrm{o}$ & $\mathrm{o}$ & $\mathrm{o}$ & $\mathrm{o}$ & $\mathrm{o}$ \\
Oxidase & - & - & - & - & - \\
Starch hydrolysis & + & + & + & + & $\mathrm{v}$ \\
Acetoin production & + & + & - & - & \\
Growth on L-alanine as carbon source & + & + & - & - & \\
Growth on 0.2\% vitamin-free casamino acids & + & + & - & - & \\
Resistance to 0.001\% cupric nitrate & - & - & + & + & \\
\hline
\end{tabular}

u Isolate re-isolated from the leaf segments showing bacterial leaf streak symptoms by inoculation with bacteria from diseased seeds.

${ }^{v}$ Pure culture of $X$. oryzae pv. oryzicola.

${ }^{\mathrm{w}}$ Isolate re-isolated from the leaf segments showing bacterial blight symptoms by inoculation with bacteria from diseased seeds.

${ }^{\mathrm{x}}$ Pure culture of $X$. oryzae pv. oryzae.

${ }^{\mathrm{y}}$ Isolate re-isolated from the leaf segments showing bacterial leaf streak symptoms by inoculation with bacteria from diseased seeds.

$\mathrm{z}+=$ positive,$-=$ negative, $\mathrm{o}=$ oxidative, $\mathrm{v}=$ variable.

Table 2. Biolog confirmation of Xanthomonas oryzae pv. oryzicola, X. oryzae pv. oryzae, and Acidovorax avenae subsp. avenae re-isolated from the leaf segments showing different symptoms

\begin{tabular}{|c|c|c|c|}
\hline \multirow[b]{2}{*}{ IRRI acc. no. ${ }^{y}$} & \multirow[b]{2}{*}{ Leaf assay ${ }^{z}$} & \multicolumn{2}{|l|}{ Biolog $x$} \\
\hline & & Identity & Similarity \\
\hline 11336 & BLS & X. oryzae pv. oryzicola & 0.82 \\
\hline 11337 & BLS & X. oryzae pv. oryzicola & 0.78 \\
\hline 11338 & BLS & X. oryzae pv. oryzicola & 0.72 \\
\hline 11339 & BLS & X. oryzae pv. oryzicola & 0.70 \\
\hline 11340 & BLS & X. oryzae pv. oryzicola & 0.81 \\
\hline 11341 & BLS & $X$. oryzae pv. oryzicola & 0.75 \\
\hline 11335 & BLB & X. oryzae pv. oryzae & 0.77 \\
\hline 08899 & BLP & A. avenae subsp. avenae & 0.80 \\
\hline
\end{tabular}

${ }^{\mathrm{x}}$ Bacteria were re-isolated from the lesions and identified by Biolog.

y International Rice Research Institute accession number.

${ }^{\mathrm{z}}$ Shows the lesions of bacterial leaf streak (BLS), bacterial leaf blight (BLB), and bacterial leaf stripe (BLP) on the leaf segments 2 to 4 days after inoculation by leaf assay. 
days appears to be the critical concentration for lesion induction based on the leaf inoculation method. At inoculum concentrations higher than $10^{5} \mathrm{CFU} / \mathrm{ml}$, the number of lesions did not increase significantly with the increase in inoculum concentration, and the incubation period remained unchanged.

Sample size of rice seeds for leaf inoculation. It appears that inoculum thresholds (minimum amount of infected seeds needed to induce the disease) varied according to levels of disease severity on mother plants from which seeds were obtained. For positive detection based on the leaf inoculation method, the minimum amount of seed obtained from mother plants with slight, intermediate, and severe BLS infection was 5.0, 2.5, and $1.0 \mathrm{~g}$, respectively, (Fig. 3A). The shortest incubation period on the leaf segments also varied with sample size and severity of infection of the mother plants (Fig. 3B). It took $10 \mathrm{~g}$ of seed from slightly and moderately infected mother plants to produce the shortest incubation period, while only $2.5 \mathrm{~g}$ of seed from severely infected mother plants was needed (Fig. 3). Ten grams of seed harvested from severely diseased mother plants yielded maximum BLS lesions on the leaf segments and the shortest incubation period, 3.5 days. To produce a similar number of BLS lesions on the leaf segments required $20 \mathrm{~g}$ of seed from mother plants with slight and intermediate BLS infection.

Confirmation test. The lesions produced on the leaf segments were typical of BLS caused by $X$. oryzae pv. oryzicola. The BLS lesions could also be distinguished using a stereomicroscope. At 7 to 14 days after inoculation with $X$. oryzae pv. oryzicola, numerous tiny drops of bacterial ooze formed on the lesions (Fig. 4), which are distinctly smaller and more numerous than those caused by $X$. oryzae pv. oryzae, while A. avenae subsp. avenae did not produce any bacterial ooze. Bacteria were re-isolated from streak lesions and their identity was confirmed by comparing them with $X$. oryzae pv. oryzicola, $X$. oryzae pv. oryzae, and $A$. avenae subsp. avenae in several bacteriological tests (Table 1).

The test tube precipitin test (micro-agglutination) revealed that a dilution of $10^{6}$, $10^{7}$, and $10^{8} \mathrm{CFU} / \mathrm{ml}$ of the re-isolated bacteria showed strong positive precipitin reaction with all dilutions of the antisera against $X$. oryzae pv. oryzicola tested. No positive reaction was observed with cell suspensions from the cultures of A. avenae subsp. avenae or the three isolates of $X$. oryzae pv. oryzae. One of the isolates of $X$. oryzae pv. oryzae showed a positive reaction, indicating that a cross-reaction between the antisera of $X$. oryzae pv. oryzicola and that of $X$. oryzae pv. oryzae is common. All six of the selected isolates from leaf segments showing BLS lesions also were confirmed by Biolog to be $X$. oryzae pv. oryzicola (Table 2).

Comparison of in vitro leaf segment and intact leaf inoculation. The incubation period and time of ooze appearance did not differ between inoculations of leaf segments in vitro and leaves on intact plants in the greenhouse. Lesions and bacterial ooze formed on leaf segments in vitro with all the inocula tested, but formed on intact plants only with the highest inoculum concentration (Table 3 ).

Comparison with IRMA. Inoculum prepared from the same rice seeds was used to detect the presence of $X$. oryzae pv. oryzicola by the leaf assay method and by IRMA. Both methods were sufficiently sensitive to detect bacteria from the seeds at all levels of disease severity tested. However, a positive reaction for $X$. oryzae pv. oryzicola also was noted with the seeds from disease-free plants of Xiang-hu 24 using IRMA and from seeds of variety Zhi 10 from mother plants with lesions of bacterial bight ( $X$. oryzae pv. oryzae positive), whereas $X$. oryzae pv. oryzicola was not detected by the leaf assay method. In another seed sample from a disease-free source, no $X$. oryzae pv. oryzicola was observed by leaf assay, while variable results were obtained by IRMA. Negative results were obtained using both methods in only one seed sample of Zhi 10 from

Table 3. Comparison of in vitro rice leaf inoculation with intact leaf inoculation in the greenhouse for detection of Xanthomonas oryzae pv. oryzicola from seeds and leaves by incubation period and ooze appearance ${ }^{\mathrm{x}}$

\begin{tabular}{lccccc}
\hline & & \multicolumn{2}{c}{ Leaf assay } & \multicolumn{2}{c}{ Greenhouse inoculation } \\
\cline { 3 - 5 } \cline { 5 - 6 } Inoculation material & Amount material & Incubation (days) & Ooze production (days) & Incubation (days) & Ooze production (days) \\
\hline Diseased seeds & $1.0 \mathrm{~g}$ & $5.0 \mathrm{a}^{\mathrm{y}}$ & $10.1 \mathrm{a}$ & no lesion & $-\mathrm{z}$ \\
Diseased seeds & $2.0 \mathrm{~g}$ & $3.0 \mathrm{~b}$ & $8.2 \mathrm{~b}$ & no lesion & - \\
Diseased seeds & $4.0 \mathrm{~g}$ & $3.0 \mathrm{~b}$ & $5.0 \mathrm{c}$ & $8.0 \mathrm{a}$ & - \\
Diseased seeds & $8.0 \mathrm{~g}$ & $2.5 \mathrm{~b}$ & $5.0 \mathrm{c}$ & $6.0 \mathrm{~b}$ & $10.0 \mathrm{a}$ \\
Diseased leaves & $2.0 \mathrm{~g}$ & $3.0 \mathrm{~b}$ & $5.0 \mathrm{c}$ & $5.0 \mathrm{~b}$ & $7.0 \mathrm{~b}$ \\
Diseased leaves & $4.0 \mathrm{~g}$ & $2.5 \mathrm{~b}$ & $5.0 \mathrm{c}$ & $5.0 \mathrm{~b}$ & $8.0 \mathrm{~b}$ \\
Pure culture & $10^{8} \mathrm{CFU} / \mathrm{ml}$ & $3.0 \mathrm{~b}$ & $6.0 \mathrm{c}$ & $5.0 \mathrm{~b}$ & \\
\hline
\end{tabular}

${ }^{\mathrm{x}}$ All the diseased seeds and leaves were collected from severely infected individual plants with bacterial leaf streak.

y Means in columns followed by the same letter are not significantly different at $P=0.05$ by the least significant difference test.

$\mathrm{z}_{-}=$not observed at end of experiment.

Table 4. Comparison of the rice leaf assay and an immuno-radiometric assay (IRMA) for detecting Xanthomonas oryzae pv. oryzicola in rice seeds

\begin{tabular}{|c|c|c|c|c|}
\hline \multirow[b]{2}{*}{ Rice cultivars } & \multicolumn{4}{|c|}{ Results of IRMA } \\
\hline & BLS scale in fieldy & $\mathbf{X s} / \mathbf{X} \mathbf{b}^{\mathbf{z}}$ & Reaction & Results of leaf assay \\
\hline Qing-lian 16 & 7.2 & 4.23 & + & + \\
\hline Shan-you 6 & 7.0 & 2.26 & + & + \\
\hline Jun-xie & 7.5 & 3.32 & + & + \\
\hline IR36 & 4.5 & 1.85 & + & + \\
\hline Xiu-shui 48 & 3.4 & 3.70 & + & + \\
\hline Shan-you 63 & 5.0 & 1.45 & $\mathrm{v}$ & + \\
\hline Xiu-shui 11 & 1.0 & 1.70 & + & + \\
\hline Xiang-hu 24 (disease-free seeds) & 0 & 2.12 & + & - \\
\hline IR26 (disease-free seeds) & 0 & 1.42 & $\mathrm{v}$ & - \\
\hline Zhi 10 (disease-free seeds) & 0 & 1.21 & - & - \\
\hline Zhi10 (bacterial blight-infected ) & 0 & 2.54 & + & - \\
\hline Zhi 10 (bacterial blight-infected ) & 0 & 1.16 & - & - \\
\hline
\end{tabular}

y $\mathrm{BLS}=$ bacterial leaf streak.

${ }^{\mathrm{z}}$ When the $\mathrm{Xs} / \mathrm{Xb}$ value was higher than 1.50 , the samples were considered "+" (infected by X. oryzae pv. oryzicola); 1.30 to 1.50 as " $\mathrm{v}$ " (suspected infection), and $<1.30$ as "-" (not infected by the bacterium). 
disease-free mother plants (Table 4). In another case, when the seed sample coming from the mother plants with severe BLS infection was treated with hot air at $80^{\circ} \mathrm{C}$ for $10 \mathrm{~min}$ to kill the bacteria, a positive reaction was observed with IRMA.

\section{DISCUSSION}

An in vitro assay for the presence of $X$. oryzae pv. oryzicola successfully detected the bacteria in washings from seed. A critical aspect of this assay is to prevent senescence of the leaf segments before the time required ( 3 to 8 days) for lesion and ooze formation from low concentrations of inoculum. This was achieved by the addition of $75 \mathrm{ppm}$ benzimidazole to the agar on which inoculated leaves were incubated.

Incubation period is governed by various factors inherent in the bacterial pathogens (species, mode of entry, inoculum density, and type of disease); the host plants (species, age, and organ of infection); and environmental conditions of infection (temperature and humidity; 6). In the leaf assay for $X$. oryzae pv. oryzicola, inoculum density was the key factor because other factors were fixed under most favorable conditions. The minimum concentration needed to induce lesions was $10^{3} \mathrm{CFU} / \mathrm{ml}$, with an incubation period of 5 to 6 days, but the percentage of leaf segments infected at this density was low. At inoculum density above $10^{5} \mathrm{CFU} / \mathrm{ml}$, the percentage of leaf segments developing lesions reached the maximum and the incubation period was the shortest.

In the leaf inoculation method, sample size in relation to seed contamination or infection is another key factor in detecting $X$. oryzae pv. oryzicola in rice seed. The lower the disease severity on mother plants, the greater the sample size of rice seed required for detection. Our results showed that the minimum sample size required for the detection of $X$. oryzae pv. oryzicola is from 1 to $5 \mathrm{~g}$ and that it varies with the disease severity of the mother plants. In reality, however, we often lack information on BLS severity in routine seed health testing for rice seed certification. Based on our data, $10 \mathrm{~g}$ of rice seed is recommended as the minimum sample size to detect $X$. oryzae pv. oryzicola using the leaf inoculation method.

Symptoms of bacterial leaf spots generally appear when the bacterial population reaches $10^{6} \mathrm{CFU} / \mathrm{ml}$ at the infection court, if the leaf tissue is congested with water (5). Incubating the leaf segments on agar provides conditions suitable for bacterial multiplication and increases the likelihood that any bacterium present will multiply to the population level required for lesion development. Therefore, even at relatively low inoculum concentration, leaf streak lesions may be produced after a sufficient time of incubation of the leaf segments. In comparison, intact leaves of rice plants grown in the greenhouse may not provide as favorable an environment. The leaf inoculation method is as fast and as efficient in testing a large numbers of seed samples as inoculation of intact leaves.

With respect to the other methods, the leaf inoculation method is more reliable and economical for detecting $X$. oryzae pv. oryzicola. IRMA is a more sensitive and faster method than leaf inoculation in detecting the bacteria, but false positive reactions were sometimes noted among seed samples from $X$. oryzae pv. oryzae-infected mother plants. This may be due to the cross-reaction of the antisera to $X$. oryzae $\mathrm{pv}$. oryzicola, which shares a common antigen with strains of $X$. oryzae pv. oryzae (19). In general, IRMA could not differentiate dead bacterial cells from living ones. The leaf inoculation method is currently being used in plant quarantine stations in China and for routine seed health testing at IRRI.

\section{ACKNOWLEDGMENTS}

We thank the Plant Protection Institute of the Zhejiang Academy of Agricultural Sciences and the plant quarantine stations in China where the detached leaf method was used for disease diagnosis and routine seed health testing; and C. Mundt and $\mathrm{M}$. Cohen for reviewing the manuscript and providing suggestions to improve clarity.

\section{LITERATURE CITED}

1. Alvarez, A. M., Benedict, A. A., and Mizumoto, C. Y. 1985. Identification of Xanthomonads and groupings of Xanthomonas campestris pv. campestris strains with monoclonal antibodies. Phytopathology 75:722-728

2. Ball, E. M. 1990. Ring interface test. Pages 149-152 in: Serological Methods for Detection and Identification of Viral and Bacterial Plant Pathogens. R. Hampton, E. Ball, and S. De Boer, eds. American Phytopathological Society, St. Paul, MN.

3. Commonwealth Mycological Institute. 1982. Descriptions of pathogenic fungi and bacteria. No. 515. Kew, Surrey, England.

4. Fang, C. T., Ren, H. C., Chen, T. Y., Chu, Y. K., Fan, H. C., and Wu, S. C. 1957. A comparison of the rice leaf blight organism with the bacterial leaf streak organism of rice and Leersia hexandra Swartz. Acta Phytopathol. Sin. 3:99-124.

5. Goto, M. 1992. Fundamentals of bacterial plant pathology. Pages 210-224 in: Academic
Press, San Diego, CA.

6. Goto, M., Zeigler, R. S., and John, V. T. 1988. Progress in seed health research on seedborne and contaminant bacterial, viruses, and nematodes. Pages 131-150 in: Rice Seed Health. International Rice Research Institute, Los Baños, Philippines.

7. Leu, L. F., and Xu, W. G. 1995. Studies on the causal factors of bacterial leaf streak of rice and strategies for integrated management. Plant Quarantine 9:74-76.

8. Mew, T. W. 1992. Management of rice diseases-a future perspective. Page 401 in: Pest Management and the Environment in 2000. A. A. Kadira and H. S. Barlow, eds. CAB International, UK.

9. Mew, T. W., Bridge, J., Hibino, H., Bonman, J. M., and Merca, S. D. 1988. Rice pathogens of quarantine importance. Pages 101-115 in: Rice Seed Health. International Rice Research Institute, Los Baños, Philippines.

10. Mew, T. W., and Misra, J. K. 1994. A Manual of Rice Seed Health Testing. International Rice Research Institute, Los Baños, Philippines.

11. Nong, X. M. 1989. Occurrence and development of bacterial leaf streak and its control strategies. Guang Xi Agric. Sci. (6):33-37.

12. Ou, S. H. 1985. Rice Diseases. 2nd ed. Commonwealth Mycological Institute. Kew, Surrey, England. 380

13. Schaad, N. W. 1982. Detection of seedborne bacterial plant pathogens. Plant Dis. 66:885890.

14. Swings, J., Van den Mooter, M., Vauterin, L., Hoste, B., Gillis, M., Mew, T. W., and Kerster, K. 1990. Reclassification of causal agents of bacterial blight (Xanthomonas campestris pv. oryzae) and bacterial leaf streak ( $X$. oryzae pv. oryzicola) of rice as pathovars of $X$. oryzae sp. nom. rev. Int. J. Syst. Bacteriol. 40:309311.

15. Vera Cruz, C. M., Gossele, F., Kersters, K., Segers, P., Vanden Mooter, M., Swings J., and Deley J. 1984. Differentiation between Xanthomonas campestris pv. oryzae, Xanthomonas campestris pv. oryzicola, and the "brown blotch" pathogen on rice by numerical analysis of phenotypic features and protein gel electrophoregrams. J. Gen. Microbiol. 130:2983-2999.

16. Wang, H. R., and Xie, G. L. 1995. Bacterial Leaf Streak of Rice and Its Management. Shanghai Science and Technology Press, Shanghai, China.

17. Wang, G. J., Zhu X. D., Chen Y. L., and Xie G. L. 1993. A rapid ELISA method for the identification of rice seeds infected by Xanthomonas oryzae pv. oryzicola. Jiangsu J. Agric. Sci. 9:36-39.

18. Xie, G. L. 1996. Characterization of Pseudomonas spp. and other bacterial species associated with rice seeds. Ph.D. thesis. International Rice Research Institute-University of the Philippines at Los Baños, Los Baños, Philippines.

19. Xie, G. L., Wang G. J., Sun S. Y., Zhou X. D., Chen J. A., Feng Z. M., and Liang M. X. 1990. Studies on rice seed inspection of Xanthomonas campestris pv. oryzicola I. Immunoradiometric assay. Chinese J. Rice Sci. 4:127-132. 